\title{
Investigation of the Levels of Blood MDA, GSH and Nitric Oxide Levels in Patients with Probable Alzheimer's Disease
}

\author{
Alzheimer Hastalı̆ı Olan Hastalarda Kan MDA, GSH ve Nitrik Oksit Düzeylerinin Araștırılması
}

\author{
Aysel Guven', Kezban Yildiz Dalginli², Hacer Culhaoglư ${ }^{3}$, Nergiz Huseyinoglu ${ }^{4}$, Selen Ilhan Alp ${ }^{5}$ \\ ${ }^{1}$ Vocational School of Health, Baskent University, Ankara; ${ }^{2}$ Kars Vocational School, Department of Chemistry and Chemical Processing \\ Technologies, Kafkas University, Kars; ${ }^{3}$ Incirliova Imam Hatip Anatolian High School, Aydin; ${ }^{4}$ Neurology Department, Acibadem \\ Hospital, Kayseri; ${ }^{5}$ Vocational School of Health Services, Namik Kemal University, Tekirdag, Turkey
}

\section{ABSTRACT}

Aim: The main focus of this study is to determine blood malondialdehyde (MDA), Glutathione (GSH) and nitric oxide (NO) levels in patients with possible Alzheimer's disease $(A D)$.

Material and Method: The study included 15 healthy persons and 15 Alzheimer's patients aged between 65 and 79 living in Kars. Before taking blood samples from patients who were diagnosed with Alzheimer at Kafkas University Faculty of Medicine Neurology Service, they were applied Standardized Mini Mental State Examination (SMMSE) and Clinical Dementia Rating. In the next step, erythrocyte GSH and serum MDA, NO levels were determined.

Results: The difference between healthy persons and Alzheimer's disease group erythrocyte GSH $(p<0.05)$ and serum MDA $(p<0.01)$, NO $(p<0.001)$ levels were statistically significant. MMSE scores were significantly lower than the control group $(p<0.001)$.

Conclusion: It was observed that $A D$ caused lipid peroxidation and as a conclusion significantly increased the MDA, GSH and NO levels in the blood of Alzheimer patients. This study supports the theory that the brain is affected by increased oxidative stress in $A D$ based on the data obtained.

Key words: Alzheimer; malondialdehyde; reduced glutathione; lipid peroxidation; nitric oxide

\section{ÖZET}

Amaç: Bu çalıșmanın amacı Alzheimer hastalığı $(A H)$ olan hastalarda kan malondialdehit (MDA), redükte Glutatyon (GSH) ve nitrik oksit (NO) seviyelerini belirlemektir.

Materyal ve Metot: Çalıșmaya Kars'ta yașayan 65 ve 79 yașları arasında 15 sağlıklı kiși ve 15 Alzheimer hastası dâhil edildi. Kafkas Üniversitesi Tıp Fakültesi Nöroloji Servisi'nde Alzheimer tanısı konan hastalardan kan örnekleri alınmadan önce Standart Mini Zihinsel Durum Muayenesi (SMMSE) ve Klinik Demans Derecesi uygulandı. Bir sonraki adımda eritrosit GSH ve serum MDA, NO seviyeleri belirlendi. Bulgular: Sağlıkı kișiler ile Alzheimer hasta grubu eritrosit GSH $(p<0,05)$ ve serum MDA $(p<0,01), N O(p<0,001)$ düzeyleri arasındaki fark istatistiksel olarak anlamlı bulundu. MMSE skorları kontrol grubundan anlamlı olarak düșük $(p<0,001)$ bulundu.

Sonuç: $A H^{\prime} ı$ lipid peroksidasyon olușumuna yol açtığı ve bunun sonucu olarak AH'nın kanındaki MDA, GSH ve NO seviyelerini önemli ölçüde arttırdığı görülmüștür. $B u$ çalıșma $A H d u-$ rumunda beynin artan oksidatif stresden etkilendiği teorisini desteklemektedir.

Anahtar kelimeler: Alzheimer; malondialdehit; glutatyon; lipit peroksidasyonu; nitrik oksit

\section{Introduction}

Alzheimer's disease (AD) is called a gradually progressing neuronal disorder disease that is symbolized by a change in behavior that reduces daily life activities and affects their ability to grasp over time. It is known that eventually the person tragically causes a decrease in quality of life and results in death. $\mathrm{AD}$ prevalence is an increasing disease ${ }^{1,2}$. Generally accepted and conclusive risk factors are age, sex, vascular diseases, malignancy, trauma, metabolic disorders, alcoholism, exposure to other toxic agents, gender and family history. Advanced age and existing of the disease of Alzheimer at the first degree relative have increased the possibility of catching the disease. The most important clinical features of $\mathrm{AD}$ are loss of memory, difficulty in daily problem solving and language and visuospatial deficits ${ }^{3-6}$. 
Oxidative stress is associated with $\mathrm{AD}$ type dementia and many other neurodegenerative disorders and it is stated to be an important factor. These relationships and effects are supported by scientific data such as biochemical, neurological findings, genetic and molecular studies $^{7-9}$.

In normal life, free radicals are formed as a result of various factors. Reactive oxygen species, DNA, proteins, lipids and carbohydrates can easily react strongly by attaching to various molecules and cause serious damage to cells ${ }^{10-11}$. Generally, the attack of reactive oxygentype agents on lipids, especially polyunsaturated fatty acids (PUFAs), can be defined as lipid peroxidation. The lipid peroxidation reaction caused by reactive oxygen species on the lipids creates some oxidation products, aldehydes. These aldehydes, which can be defined in various biological structures, form biologically active molecules that create new oxidative damage. There are common pathological processes associated with malondialdehyde (MDA), one of the most studied of these aldehydes ${ }^{12}$.

It is stated that free radicals play an effective role in the exposure of a large number of physiological and neurological diseases and the progression of the disease course. Oxidative stress caused by free radicals has been associated with the etiopathogenesis of neurogenerative diseases such as Huntington, Parkinson and Alzheimer's disease, and some neuropsychiatric diseases such as anxiety, schizophrenia disorders and depression or bipolar disorder ${ }^{7,13-15}$.

In relation to this, it states that the individuals with Alzheimer's type dementia and cognitive impairment have high the amount of of lipid peroxidation agents in the central nervous system and environmental tissues ${ }^{15,16}$.

It has been shown to be closely related to neurodegeneration, which is the result of oxidative stress-induced damage in the brain of Alzheimer's disease. In addition, there are various links between oxidative stress and the formation of amyloid plaques and antioxidant enzymes. Therefore, it is stated that oxidative damage leads to changes in the certain activity of the antioxidant system and consequently mitochondrial disorders ${ }^{8,11,13,16}$.

Physiological aging is seen as an inevitable process that gradually develops due to the collection of some oxidative lesions. It is stated that cell, tissue or organ injuries caused by uncontrolled oxidative stress are caused by the disparity between oxidants and antioxidants. This imbalance, which can lead to homeostasis, is caused by the weakening of antioxidant barriers and non-enzymatic antioxidant factors, including enzymes ${ }^{2,16-18}$. Therefore, it is suggested that excessive aggregation of free radicals triggers antioxidant defenses and leads to reduction of the body's antioxidant reserves ${ }^{15,16}$.

Glutathione $(\mathrm{GSH})$, an antioxidant, is present in many cells in milimolar concentrations. It is also the most common antioxidant in the brain. It is known that GSH, which contains thiol in its structure, reacts with ROS, nucleophilic compounds and lipid peroxidation products and shows a protective effect against them. Reduced GSH, which can react with free radicals, forms oxidized glutathione (GSSG) via the glutathione peroxidase (GPx) enzyme. GSSG is converted into GSH molecules via GSH reductase (GR) using reduced equivalent $\mathrm{NADPH}^{10,17,19}$.

$\gamma$-glutamylcysteine ligase and glutartion synthase enzymes are involved in the synthesis of GSH, which consists of glutamate, cysteine and glycine amino acids. Because the amount of cysteine present in the brain reduces the formation of GSH, most studies have focused on indirectly increasing the levels of GSH in the brain. In this context, it is stated that N-acetyl-Lcysteine (NAC) directly increases the physiological levels of cysteine in the brain and increases it to GSH biosynthesis both in and around the brain ${ }^{20}$. In addition, it is stated that $\gamma$-Glutamylcysteine ethyl ester (GCEE) is the stimulant of cysteine, which plays a role in increasing GSH biosynthesis in the brain and its surroundings. It is also stated that $\gamma$-glutaminecysteine ligase is the precursor to the last phase in GSH synthesis, avoiding feedback inhibition. It is stated that astrocytes, the neuroinflammatory component that is prominent in $\mathrm{AD}$, are the main supplier of GSH in microglia and neurons. In the presence of oxidative stress, these astrocytes are said to release toxic mediators, such as free radicals, causing inflammatory agents that accelerate neuronal disruption ${ }^{21}$.

Among the other oxidative stress sources or modulators associated with $\mathrm{AD}$, one of its important mechanisms is stated to be Nitric Oxide (NO). Reports investigating the mechanisms by which oxidative stress triggers certain disruptions in NO releasing and expressing its physiological and pathophysiological importance for neuronal disruption in $\mathrm{AD}$ are presented ${ }^{22,23}$.

During aging and pathological processes, it is expressed that NO behavior can be harmful when it reacts with the superoxide anion to form peroxide ${ }^{24}$. It is stated 
that NO and oxidative stress play a very important role in the early and advanced stages of neurodegenerative diseases and at the same time contributing to their progress. In neurodegenerative diseases, it has been recognized as a key factor in the mechanisms of NO-mediated vascular disorder, particularly in which it emphasizes the effect of reactive oxygen species $^{25}$.

\section{Material and Method}

The study included 15 healthy persons and 15 Alzheimer's patients aged between 65 and 79 living in Kars. Before taking blood samples from patients who were diagnosed with Alzheimer at Kafkas University Faculty of Medicine Neurology Service, they were applied Standardized Mini Mental State Examination (SMMSE) and Clinical Dementia Rating ${ }^{26}$. Then, levels of erythrocyte GSH and serum MDA, NO were determined.

\section{Serum Analyses}

It has been determined according to the method of Placer et al, which is based on the chromogen color measurement formed as a result of thiobarbituric acid (TBA) reaction with MDA, which is the final product of polyunsaturated fatty acid peroxidation ${ }^{27}$. As a standard, the solution concentration of 1.1.3.3-tetraethoxypropane (Sigma Chemical Company St. Louis, MO, USA) prepared at the rate of 0, 0.05, 0.1, 0.15 and $0.2 \%$ was used. The results were measured using TBAMDA extinction coefficient $(\varepsilon=153 \mathrm{nmol} 1-1 \mathrm{~cm}-1)$ and expressed in malondialdehyde (MDA) concentration ( $\mathrm{nmol} / \mathrm{ml}$ serum). Nitric oxide determination in plasma was determined spectrophotometrically by Miranda et al. ${ }^{28}$. The nitrate and nitrite concentrations were determined by looking at the calibration curve and NO concentration was found.

\section{RBC Analyses}

The GSH level of hemolized RBC was determined spectrophotometrically using Ellman's reagent ${ }^{29}$. According to the cyanemhemoglobin method, hemoglobin concentration was determined in lysed erythrocytes.

\section{Results}

The focus of this dissertation is the research of MDA, GSH and NO levels in blood samples taken from Alzheimer's patients. (Table 1). In our study, newly diagnosed Alzheimer's patients were younger than the other part of the study group. However, there is a correlation $(\mathrm{CC}=0.56, \mathrm{p}<0.05)$ between the diagnosis time and age. The most noticeable changes in the parameter values associated with oxidative stress were found in the newly diagnosed AD group. Compared to control, MDA level was found to be high in both newly diagnosed patients and patients with long-term neuronal disorders. Moreover, the data in the two groups were statistically significant. GSH levels were significantly lower in newly identified patients compared to controls. NO parameter levels were significantly higher in the patient group compared to the healthy group. Similarly, MMSE scores were also significantly lower in the patient group than in the control, in line with other parameters $(\mathrm{p}<0.001)$.

\section{Discussion}

Oxidative damage has proven to be a serious factor in the formation and continuation of neurodegenerative disorders. It is also likely identified as a direct initiation factor in neurodegeneration.

Oxidative damage is one of the main etiopathogenetic factors of AD. Oxidative damage that is common in the brain in $\mathrm{AD}$ has been associated with aging. Free radical species that cause oxidative damage damage organic molecules such as protein, lipid, cellular organelles such as mitochondria and DNA. So it can activate the cell cycle. It contributes to neuronal damage by limiting endogenous antioxidant defenses in the brain ${ }^{30,31}$.

Some reports support that oxidative and nitrosative stress is an active factor in the manner of development of $\mathrm{AD}^{32,33}$. The current link between oxidative damage caused by oxidative stress-induced ROS production and $\mathrm{AD}$ amyloid- $\beta(\mathrm{A} \beta)$ plates and their results for molecules associated with them is stated at the molecular level ${ }^{34}$.

Table 1. Statistical comparison of erythrocyte GSH and serum MDA and NO values in groups

\begin{tabular}{lccc}
\hline & & Control & Experimental \\
& $N$ & $X \pm S D$ & $X \pm S D$ \\
\hline MDA $(\mathrm{nmol} / \mathrm{ml})$ & 15 & $7.59 \pm 0.20^{\star}$ & $8.81 \pm 0.65^{\star}$ \\
GSH $(\mu \mathrm{mol} / \mathrm{ml})$ & 15 & $6.13 \pm 0.16^{\star \star}$ & $6.28 \pm 0.36^{\star *}$ \\
NO $(\mu \mathrm{mol} / \mathrm{ml})$ & 15 & $28.70 \pm 0.47^{\star \star *}$ & $33.01 \pm 1.08^{\star \star *}$ \\
MMSE & 15 & $26 \pm 1.43^{\star \star *}$ & $13 \pm 2.31^{\star \star *}$ \\
\hline
\end{tabular}

$\mathrm{N}$ : Number of individuals in each group

$\mathrm{X} \pm \mathrm{SD}$ : Mean \pm Standard deviation

${ }^{*} \mathrm{p}<0.01 ;{ }^{* *} \mathrm{p}<0.05 ;{ }^{* \star *} \mathrm{p}<0.001$ 


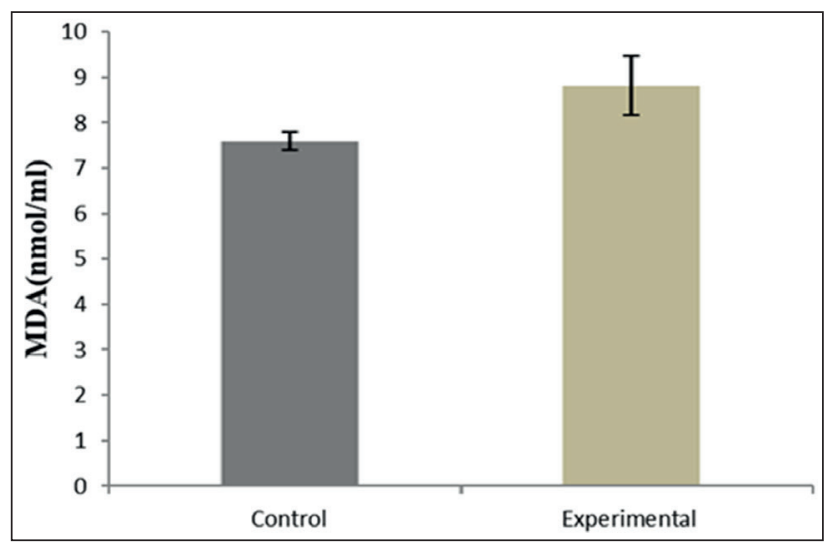

Figure 1. GSH levels in healthy group and Alzheimer patients.

Lipid peroxidation products have been highly associated with the development and progression of $\mathrm{AD}^{35,36}$. Therefore, we have worked as potential biomarkers of disease. In our study, MDA caused by free radicals affecting lipids was found to be significantly higher in $\mathrm{AD}$ group (Figure 1). The increase of free radical damage products in $\mathrm{AH}$ is consistent with the results of other investigators ${ }^{16,37}$. As potential biomarkers for $\mathrm{AD}$, some lipid peroxidation products was examined in human samples with variable results. MDA is the most evaluated biomarker in blood samples. In general, AD patients had higher serum levels than healthy subjects $^{38}$. In plasma, MDA levels have been shown to be higher in patients than in healthy individuals ${ }^{39}$. In all cases; MDA, which is an indicator of oxidative stress and especially lipid peroxidation, can be said to be the molecular biomarker which is effective in the early development of $A D$.

It is stated that GSH levels decrease in other age-related neurodegenerative diseases including $\mathrm{AD}^{40}$. In peripheral lymphocytes of AD, GSH levels decrease due to the increase of oxidative stress and GSSG levels increase accordingly. In studies, the ratio of GSSG to GSH is often used as a definition of redox thiol status and oxidative stress. It was found that as AD progresses, both GSSG and GSSG/GSH rates increase. Both colorimetric methods and HPLC methods have been developed to determine GSSG and total GSH (GSH + GSSG) levels ${ }^{41-44}$. In some studies, the level of GSH in individuals with Alzheimer's is lower than in healthy people. Antioxidant use increases in Alzheimer's patients due to the effects of free radicals, resulting in decreased levels of antioxidants ${ }^{45-47}$. However, in our study, an increase in GSH values was observed (Table
1). In Alzheimer's disease, glutathione levels are expected to decrease due to the drop of astetilcholine. On the other hand, it was concluded that the drugs used by the patients in our study increased the level of acetylcholine and that the increased acetylcholine provided the cysteine amino acid required for the synthesis of glutathione. In addition, differences in food consumption habits of patients included in the study may affect the level of glutathione. As a further point of view, it was concluded that free radicals would increase the level of glutathione in order to eliminate the harmful effects of free radicals in the organism.

$\mathrm{NO}$, a gaseous molecule that can easily spread to the surrounding tissue, is synthesized by an enzymatic activity performed by the family of NO synthase (NOS) oxidizing citrulline and L-arginine (L-Arg). Potential NO sources in the brain are neurons, glia, and vascular cells that can express $\mathrm{NOS}^{24}$. In neurodegenerative diseases, especially NO-mediated vascular disorder is considered to be an important factor in the mechanisms that emphasize the effect of reactive oxygen species $^{48}$. The latest literature shows that oxidative stress together with NO plays a role in both early and advanced stages of neurodegenerative diseases and that it supports their progression ${ }^{23,49,50}$. In some studies, postmortem brain tissues have been shown to cause free radical formation in some studies and pathological changes related to it have been described ${ }^{30,51}$. In a study conducted in control and Alzheimer's patients, neurons of Alzheimer's patients had diffuse amounts of iNOS, but no was found in control individuals ${ }^{52}$. In another study, nNOS, (inducible nNOS) iNOS and nitrosin-nitrate values of NOS isoforms (neuronal nNOS) from the cortex of the post-mortem brain of Alzheimer's patients were analyzed, and immunoreactivity of nNOS, iNOS and nitrotyrosin were recorded in neuron and glial cells ${ }^{53}$. The NO level difference in the plasmas between healthy and Alzheimer patients' groups are found statistically significant $(\mathrm{p}<0.001)$ (Figure 2). In conclusion, in our study, NO level was found to be high in patients with AD. It was concluded that increased NO level in AD may be increased by nNOS and iNOS related to the learning and memory part of the brain.

Standard Mini Mental Test (SMMT) is the most common test used to quantitatively evaluate cognitive performance in standard neuropsychiatric examination methods. Nowadays, clinical practice is used to detect cognitive disorders, to monitor the course of demented syndromes and to monitor responses to treatment. 


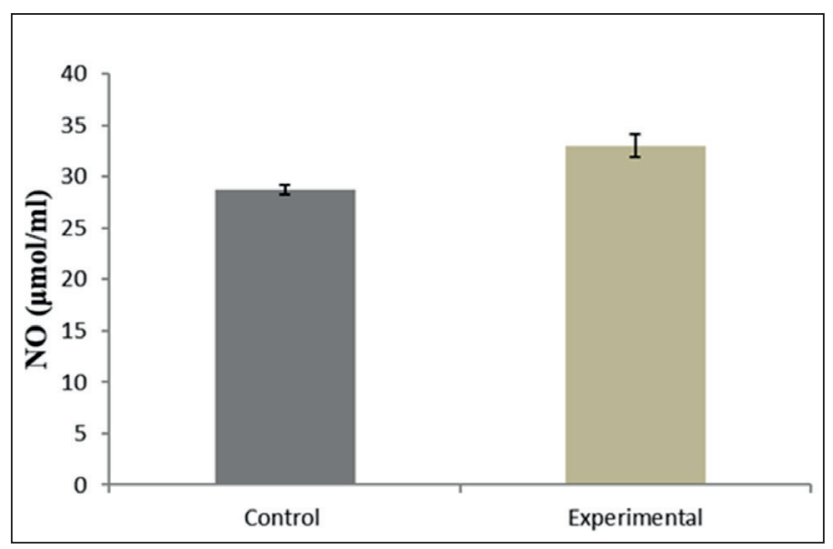

Figure 2. NO levels in healthy group and Alzheimer patients.

Also, it is a popular test which is applied in epidemiological studies about elderly people living in the community or in an institution ${ }^{54}$. When the results were evaluated, it was seen that the patients in the study group were statistically higher than the control group (Table 1). These findings are consistent with previous studies ${ }^{45,46,55,56}$.

Consequently, these data support the idea that oxidative stress has a prominent feature in the development or triggering of $\mathrm{AD}$. In addition, we believe that increases and changes in oxidative stress parameters can be a guide in both early and later stages of $\mathrm{AD}$. Also, the increase in the amount of lipid peroxidation and the decrease in the amount of antioxidants can direct the curative options of affected parameters specific to $\mathrm{AD}$ at the time after diagnosis of the disease.

\section{Ethical Approval}

Ethical committee approval of this study has been obtained from the Ethics Committee of Kafkas University (Date: 25.02.2011, Number: 2011/03).

\section{References}

1. Gilman S. Alzheimers disease. Perspect Biol Med. 1997;40:23045 .

2. Terry RD, Masliah E, Salmon DP, Butters N, DeTeresa R, Hill R et al. 1991. Physical basis of cognitive alterations in Alzheimer's disease: synapse loss is the major correlate of cognitive impairment. Ann Neurol. 1991;30:572-80.

3. Law A, Gauthier S, Quirion R. Say NO to Alzheimer's disease: the putative links between nitric oxide and dementia of the Alzheimer's type. Brain Research Reviews 2001; 35: 73-96.
4. Gandhi S, Abramov AY. Mechanism of oxidative stress in neurodegeneration. Oxid Med Cell Longev 2012; doi: $10.1155 / 2012 / 428010$.

5. Winslow BT, Onysko MK, Stob CM, Hazlewood KA. Treatment of Alzheimer disease. Am Fam Physician 2011; 83:1403-12.

6. Beal MF. Oxidative damage as an early marker of Alzheimer's disease and mild cognitive impairment. Neurobiol Aging 2005;26:585-6.

7. Padurariu M, Ciobica A, Hritcu L, Stoica B, Bild W, Stefanescu C. Changes of some oxidative stress markers in the serum of patients with mild cognitive impairment and Alzheimer's disease. Neurosci Lett 2010; 469:6-10.

8. Padurariu M, Ciobica A, Lefter R, Serban IL, Stefanescu C, Chirita R. The oxidative stress hypothesis in Alzheimer's disease. Psychiatr Danub 2013; 25:401-9.

9. Massaad CA: Neuronal and vascular oxidative stress inAlzheimer's disease. Curr Neuropharmacol 2011; 9:662-73.

10. Halliwell B. Oxidants and human disease: some new concepts. FASEB J. 1987; 1:358-64.

11. Evans $\mathrm{PH}$. Free radicals in brain metabolism and pathology. $\mathrm{Br}$ Med Bull 1993; 49:577-87.

12. Ayala A, Muñoz MF, Argüelles S. Lipid peroxidation: production, metabolism, and signaling mechanisms of malondialdehyde and 4-Hydroxy-2-nonenal. Oxid Med Cell Longev 2014;2014:360438

13. Uttara B, Singh AV, Zamboni P, Mahajan RT. Oxidative stress and neurodegenerative diseases: a review of upstream and downstream antioxidant therapeutic options. Curr Neuropharmacol 2009;7:65-74.

14. Salim S. Oxidative stress and the central nervous system. J Pharmacol Exp Ther 2017;360:201-5.

15. Greilberger J, Koidl C, Greilberger M, Lamprecht M, Schroecksnadel K, Leblhuber F et al. Malondialdehyde, carbonyl proteins and albümin-disulphide as useful oxidative markers in mild cognitive impairment and Alzheimer's disease. Free Radic Res 2008; 42:633-8.

16. Baldeiras I, Santana I, Proença MT, Garrucho MH, Pascoal $\mathrm{R}$, Rodrigues A et al. Peripheral oxidative damage in mild cognitive impairment and mild Alzheimer's disease. J Alzheimers Dis. 2008;15:117-28.

17. Sies H. Oxidative stress: oxidants and antioxidants. Exp Physiol 1997; 82:291-5.

18. Shukla V, Mishra SK, Pant HC. Oxidative stress in neurodegeneration. Adv Pharmacol Sci 2011; 572634.

19. Pocernich CB., Butterfield DA. Elevation of glutathione as a therapeutic strategy in Alzheimer disease. Biochimica et Biophysica Acta 2012; 1812:625-30.

20. Mokhtari V, Afsharian P, Shahhoseini M, Kalantar SM, Moini A. A Review on various uses of N-Acetyl Cysteine. Cell J. 2017;19: 11-17.

21. Glass CK, Saijo K, Winner B, Marchetto MC, Gage FH. Mechanisms underlying information in neurodegeneration, Cell. 2010;140:918-34. 
22. Huang WJ, Zhang X and Chen WW. Role of oxidative stress in Alzheimer's disease (Review) Biomedical Reports 2016; 4: 519-22.

23. Spiers J G, Cortina Chen HJ, Bourgognon JM, Steinert JR. Dysregulation of stress systems and nitric oxide signaling underlies neuronal dysfunction in Alzheimer's disease. Free Radical Biology and Medicine 2019; 134: 468-83.

24. Picón-Pagès P, Garcia-Buendia J, Muñoz F J. Functions and dysfunctions of nitric oxide in brain. BBA-Molecular Basis of Disease 2019; 1865:1949-67.

25. Venturelli M. The Role of nitric oxide on vascular dysfunction during aging and Alzheimer's disease. In: Therapeutic Application of Nitric Oxide in Cancer and Inflammatory Disorders 2019; 221-228.

26. Berg L. Clinical dementia rating. Br J Psychiatry 1984;145:339.

27. Placer ZA, Cushman LL, Johson BC. Estimation of Product of Lipid Peroxidation (Malonyl Dialdehyde) In Biochemical Systems. Anal Biochem 1966;16: 359-64.

28. Miranda KM, Espey MG, Wink DA. A Rapid, simple spectrophotometric method for simultaneous detection of nitrate and nitrite. Nitric Oxide 2001;5:62-71.

29. Sedlak J, Lindsay RH. Estimation of total protein-bound and non-protein sülfhdryl groups in tissue with Ellman's reagent. Anal Biochem 1968;25:192-205.

30. Lovell MA, Markesbery WR. Oxidative damage in mild cognitive impairment and early Alzheimer's disease. J Neurosci Res. 2007;85:3036-40.

31. Montine TJ, Neely MD, Quinn JF, Beal FM, Markesbery WR, Roberts LJ et al. Lipid peroxidation in aging brain and Alzheimer's disease. Free Radic Biol Med 2002;33:620-6.

32. Butterfield DA, Bader Lange ML, Sultana R. Involvements of the lipid peroxidation product, $\mathrm{HNE}$, in the pathogenesis and progression of Alzheimer's disease, Biochim. Biophys. Acta 2010;1801:924-9.

33. Wang X, Wang W, Li L, Perry G, Lee HG, Zhu X. Oxidative stress and mitochondrial dysfunction in Alzheimer's disease, Biochim Biophys Acta 2014;1842:1240-7.

34. Cheignona C, Tomasa M, Bonnefont-Rousselot D, Faller P, Hureau C, Collin F. Oxidative stress and the amyloid beta peptide in Alzheimer's disease. Redox Biology 2018;14:450-64.

35. Giavarotti L, Simon KA, Azzalis LA, Fonseca FLA, Lima AF, Freitas MCV et al. Mild systemic oxidative stress in the subclinical stage of Alzheimer's disease. Oxidative Med Cell Longev 2013;609019.

36. Peña-Bautista C, Vigor C, Galano JM, Oger C, Durand T, Ferrer I et al. Plasma lipid peroxidation biomarkers for early and noninvasive Alzheimer disease detection. Free Radic Biol Med 2018;124:388-94.

37. Kheradmand E, Moghaddam AH, Zare M. Neuroprotective effect of hesperetin and nano-hesperetin on recognition memory impairment and the elevated oxygen stress in rat model of Alzheimer's disease. Biomedicine Pharmacotherapy 2018:97;1096-1101.
38. Shinto L, Quinn J, Montine T, Dodge HH, Woodward W, Baldauf-Wagner $S$, et al. A randomized placebo controlled pilot trial of omega-3 fatty acids and alpha lipoic acid in Alzheimer's disease. J Alzheimers Dis 2014;38:111-120.

39. Yuan L, Liu J, Ma W, Dong L, Wang W, Che R et al. Dietary pattern and antioxidants in plasma and erythrocyte in patients with mild cognitive impairment from China. Nutrition 2016;32:193-8.

40. Luo Y, Roth GS. The roles of dopamine oxidative stress and dopamine receptor signaling in aging and age-related neurodegeneration. Antioxidants Redox Signaling 2004; doi. org/10.1089/15230860050192224

41. Rahman I, Kode A, Biswas SK. Assay for quantitative determination of glutathione and glutathione disulfide levels using enzymatic recycling method. Nat Protoc 2006; 1:3159-65.

42. Tietz F. Enzymatic method for quantitative determination of nanogram amounts of total and oxidized glutathione: application to mammalian blood and other tissues. Analytical Biochemistry 1969;27:502-22.

43. Martensson J. Method for determination of free and total glutathione and $\gamma$-glutamylcysteine concentrations in human leukocytes and plasma. Journal of Chromatography 1987;420:152-7.

44. Mopper K. Trace determination of biological thiols by liquid chromatography and precolumn fluorometric labeling with o-phthalaldehyde. Anal Chem 1984;56:2557-60.

45. Akkaya C, Sahin Yavuzer S, Yavuzer H, Erkol G, Bozluolcay M, Dinçer Y. DNA damage, DNA susceptibility to oxidation and glutathione redox status in patients with Alzheimer's disease treated with and without memantine. J Neurol Sci 2017;378:158-162.

46. Mandal PK, Saharan S, Tripathi M, Murari G. Brain glutathione levels-a novel biomarker for mild cognitive impairment and Alzheimer's disease. Biological Psychiatry 2015;78:702-10.

47. Güzel S, Yıldız Ö, Ünal A, Kızıler AR, Gülyaşar T, Celik Güzel E, et al. Doublecortin-like kinase 1 levels and oxidant status in Alzheimer's disease. Cukurova Medical Journal 2017;42:687-693.

48. Venturelli M. The role of nitric oxide on vascular dysfunction during aging and Alzheimer's disease. Therapeutic Application of Nitric Oxide in Cancer and Inflammatory Disorders 2019;221-228.

49. Lourenço CF, Ledo A, Barbosa RM, Laranjinha J: Neurovascular uncoupling in the triple transgenic model of Alzheimer's disease: Impaired cerebral blood flow response to neuronal-derived nitric oxide signaling. Experimental Neurology 2017;291:36-43.

50. Smith MA, Rottkamp CA, Nunomura A, Raina AK, Perry G. Oxidative stress in Alzheimer's disease. Biochim Biophys Acta 2000;1502:139-44.

51. Markesbery WR. Oxidative Stres Hypothesis in AD. Free Radic Biol Med 1997;23:134-147. 
52. Wong A, Lüth HJ, Deuther-Conrad W, Dukic-Stefanovic S, Gasic-Milenkovic J, Arendt T et al. Advanced glycation endproducts co-localize with inducible nitric oxide synthase in Alzheimer's disease. Brain Research 2001;920:32-40.

53. Fernández -Vizarra P, Fernández AP, Castro-Blanco S, Encinas JM, Serrano J, Bentura MLet al. Expression of nitric oxide system in clinically evaluated cases of Alzheimer's disease. Neurobiol Dis 2004;15:287-305.

54. Brossard B. 4-Objectifying dementia: The use of the minimental state exam in medical research and practice. Psychiatry Science and Society 2018;127-154.
55. Tzimourta KD, Afrantou T, Ioannidis P, Karatzikou M, Tzallas AT et al. Analysis of electroencephalographic signals complexity regarding Alzheimer's Disease. Computers and Electrical Engineering 2019;76:198-212.

56. Santabarbara J, Gracia-Rebled AC, Lopez-Anton R, Tomas C, Lobo E, Marcos G, et al. The effect of occupation type on risk of Alzheimer's disease in men and women. 2019;126:61-8. 